\title{
Edyta Lorek-Jezińska
}

Nicolaus Copernicus University, Poland

https://orcid.org/0000-0002-5492-4255

e-mail: lorek@umk.pl

Nelly Strehlau

Nicolaus Copernicus University, Poland

https://orcid.org/0000-0001-7670-7860

e-mail: strehlau@umk.pl

\section{Katarzyna Więckowska}

Nicolaus Copernicus University, Poland

https://orcid.org/0000-0003-3408-3695

e-mail: klew@umk.pl

\section{Perspectives on Authorship and Authority}

\begin{abstract}
This article outlines selected shifts in thinking about authorship and authority that have occurred in literary and cultural studies in the aftermath of Roland Barthes's proclamation of the death of the author, followed by the author's many revivals. Reconsidering Barthes's seminal essay and confronting it with Michel Foucault's query about the author-function, the article comments on Seán Burke's polemical stance concerning situated authorship. Against these general considerations, several areas in which authorship and authority have been reconceptualized are briefly discussed, referring to the themes addressed in this volume. These areas embrace the problems of representing and using somebody else's story in visual arts and testimonial theatre, the challenges of individual and cultural situatedness of writing within one's own output and in reference to more general cultural hauntings as well as the processes of self-formation in the interactions between a variety of texts forming life-writing.
\end{abstract}

Keywords: authorship, authority, death of the author, responsibility, testimony, life-writing

More than half a century ago, Roland Barthes proclaimed the death of the author and welcomed the birth of the reader. His influential essay was instrumental in redefining the place of the author and the reader in the process of interpretation and negotiation of meanings, questioning the traditional discourses of authorship, and decentralizing authorial practices. And yet, much like other spectres of cultural and literary studies, the figure of the author refuses to cease its haunting. 
On the contrary: the debate on authorship remains as lively as it has ever been, and transcends the academic discourse, spilling over into all kinds of texts, from fanworks, to social media posts, to Internet poetry. Regardless if the discussion concerns texts that represent new media or traditional forms, at its heart remains the same question: that of authority and its situatedness.

Critical discussions of the relationship between authors and texts frequently stress the connection between authorship, authority, power, and control. In his seminal essay, Barthes consistently links authorship with social forces and power to present the author as "a product of our society" (2000: 147) and a tangible manifestation of its rules, which confer the right to author to some subjects while denying it to others. If to become an author is to be endowed with authority and power, then the "removal of the Author ... utterly transforms the ... text" (2000: 148), freeing it from the existing bonds but also entangling it in new ones. Barthes calls this new type of text performative, thereby pointing to the newly gained authority of the reader as well as indicating other pressures exercised on the text. The performative character of writing, the fact that "every text is eternally written here and now" (2000: 149), opens the space for multiple readings and various operations of power, and makes every encounter with the text both a liberating and restricting experience which re-inscribes into the text the rules and values of the readers' present.

The potential dangers associated with rejecting the traditional function of the author were famously commented on by Michel Foucault, who in his 1969 essay pointed to the need to "locate the space left empty by the author's disappearance, follow the distribution of gaps and breaches, and watch for the openings that this disappearance uncovers" (2000: 177). In his "What is an Author?" Foucault stresses the importance of ownership of literary texts and discusses "author" as a function of discourse, "the ideological figure by which one marks the manner in which we fear the proliferation of meaning" (2000: 186). Speculating on the future of texts, he envisages a time when "the author-function will disappear," yet only to be replaced by a different method in which fiction will operate, "another mode, but still with a system of constraint - one which will no longer be the author, but which will have to be determined or, perhaps, experienced" (Foucault 2000: 186). Accordingly, a new set of questions will have to be asked to address this new mode of functioning of texts, regarding their circulation, appropriations, and power effects (Foucault 2000: 187).

Others have also warned against approaching the death of the author too uncritically. Seán Burke argues that the death of the author, or more broadly, the death of the subject in postmodernism, ought to be seen as intrinsically contradictory: to "dethrone the author" (1999: 27), Barthes had to first "create a king worthy of the killing" (1999: 26). Elsewhere, Burke stresses that "[w]ith unavoidable irony, the theory of authorial absence no more signalled a disengagement with issues of authorship than iconoclasm attests to the dwindling of the icons, or negative theology reflects an indifference to Divinity. The ancient chimeras of origin and authorship reassert themselves in the very gestures that seek to have done with origin and authorship" (Burke 2006: xvi). Burke also cautions that " $[\mathrm{t}]$ he need to ground authorship should be felt most intensely within political forms of literary criticism" (1999: 202) precisely in order to see the text as particular, situated, historically determined and relevant to ethical considerations of feminist or postcolonial studies: the readerly freedom achieved at the cost of "deracination" of the text may deprive it of meanings rather than assist in their proliferation (1999: 203).

The articles collected in this volume explore the spaces of resistance opened up and restrictions imposed by the critical gestures of Roland Barthes and Michel Foucault. The authors investigate various positions created for the reader and the author in $20^{\text {th }}$ - and $21^{\text {st }}$-century texts and examine the responsibilities of speaking for the other and the consequences of the awareness that 
every text is "a tissue of quotations drawn from the innumerable centres of culture" (Barthes 2000: 149). The practice of recycling and using works authored by others, which has been identified as one of strategies testifying to the exhaustion of postmodern culture, or the "death of the subject" (Jameson 1993: 195) mentioned above, thus engages with significant questions of positionality and the complex ethics of narrating somebody else's story. This aspect is of particular relevance to the practices of retelling the story of "another's wound" (Caruth 1996: 8). In the context of postmemory (Hirsch 2008) and transgenerational and cultural trauma (Alexander 2004), authority and authorship are embedded in the collective or inherited experience of the traumatic event, which places particular demand and responsibilities on individual responses.

The links between authorship, responsibility, and the right to re-tell somebody else's story are explored in Anna Kisiel's "Gazing at Eurydice: Authorship and Otherness in Bracha L. Ettinger," which discusses the role played in Ettinger's work by a photograph of women and children from the Mizocz ghetto, taken by an anonymous photographer in 1942. Referring to Ettinger's matrixial theory, Kisiel analyses Eurydice, No. 5 and an untitled sketch from 1985, to show how the artist resubjectifies the dead women and creates a space for a relation between the author, the work, and the viewer that is based on intimacy, shareability, and compassion. A key element in the discussion of the spectral presence of the Mizocz women is the notion of trauma and the problem of representing the suffering of the other without appropriating it. As Kisiel convincingly argues, Ettinger's mediation of (original) trauma through various re-constructions of the photograph of the Mizocz women gives rise to ethical questions about authors and their responsibility and realises the humanising potential of authorship by re-presenting experiences that have been silenced or appropriated.

Ethical questions are also central to authority and authorship in testimonial narratives and witnessing. The popularity of forms based on testimony and witnessing, including testimonial theatre, as Clare Summerskill notes, has emerged from the general "distrust of mainstream media" and "seeking alternate versions of events and information provided in the form of personal narratives" (2021: 4). The interest of verbatim theatre (which it shares with oral history) in "testimonies from members of marginalised, vulnerable or previously silenced populations" (Summerskill 2021: 4) illustrates one of the central premises of this volume, of the emergence of alternative authors with the downplaying of the role of "traditional" authorships. What is especially significant in this type of authorship is a particular relationship between the "authors" of testimonial theatre, which can be based on the "authority [...] rooted in its promise of an ethical and honest creative process, established upon relationships of care and trust" (Stuart Fisher 2020: Introduction). The difficulty of this shared authorship is further complicated by the problematic nature of traumatic memory (Caruth 1995; Felman and Laub 1992), the interaction between testimony and witnessing, connected with responsibility and taking action (Kaplan 2005: 122-23; Felman and Laub 1992: 24), as well as the experience of vicarious trauma (Kaplan 2005: 40). Some of these issues are addressed by Andrea Bellot in "Authoring war memories: War memoir writing and testimonial theatre performances," in which she discusses theatrical forms consisting in re-enactment of the war experience of their authors. Her article covers the history of war writing, the inherent difficulties associated with the effects of war on memory, and the ideological as well as medical dimensions of the form. Bellot argues that even though the collaborative authorship and experimental, non-professional form of theatre of testimony can be seen to seek to undermine the notion of a single story and its claim to objectivity and truth, as well as destabilise the accepted, known narratives about the war presented in the mass media, their authority and audience's belief in their veracity are ultimately derived from the figure of the veteran author, often performing in person or impersonated by an actor, whose status as first-hand witness provides the story with legitimacy. 
In her introduction to The Deaths of the Author, Jane Gallop makes two observations that are significant for this volume's preoccupation with authors. The first - more general - is that "the author's death makes the reader think more not less about the author" (2011: 1), referring to both its conceptual reading as the aftermath of the poststructuralist legacy and a more individual comment on how the recent death of an author might impact the reading of their works. This second, more individual aspect highlights the peculiarities of re-reading the works of authors after their death, and leads to the second observation made by Gallop - on a particular "poignancy" that the reading process gains when the "book is haunted by the [recent] death of the author" (2011: 1). In her article on A Particle of Dread (Oedipus Variations), Paulina Mirowska reads Sam Shepard's last play posthumously, placing it within the context of the author's individual artistic career and with reference to the idea of self-invention. Simultaneously, by tracing the connection of Shepard's last play to other texts and cultural contexts, by exploring its intertextuality, metatheatricality and cultural identification, Mirowska points to the significance of situatedness of authors, texts and readings. Contextualising her discussion in an overview of Sam Shepard's dramatic oeuvre, which, as Jeanette R. Malkin notes, was "in a constant state of self-transformation," (1999: 115) Mirowska demonstrates how the search for identity and constant effort towards re-inventing oneself shaped the playwright's works. A Particle of Dread (Oedipus Variations) is presented as a culmination of the author's search for self-expression, yet it also points to external cultural processes at play, such as the critics' inclusion of Shepard in the Irish dramatic canon, emphasising, among others, Shepard's predilection for story-telling reminiscent of the Irish playwriting tradition. In this context, the play that, as Mirowska argues, refuses to "resolve the conflict between various perspectives on such matters as the nature of identity, the search for meaning and value in contemporary culture, or the creative process itself," at the same time resonates strongly with its first audiences by referring to "histories of unhealed communal and individual traumas."

The concepts of authorship and haunting lead us to important questions about the relation between texts and authors as well as the problems of authority and power. With its various conceptualisations as both constricting and liberating, spectrality can signify the persistence of the past in the present and indirectly point to forms of continuity and tradition, however evanescent. ${ }^{1}$ It is within such tradition of haunting that authors are often placed or to which they are interpreted to refer. Yet haunting brings another angle to authorship and authority by highlighting the problems of veracity or legitimacy of the haunting voice. Whether as a feeble expression of the dispossessed or marginalized, or the one in power, the spectral voice always acquires a sense of urgency connected to responsibility and knowledge (Derrida 2006: xix), which makes the ghost a figure to "reckon with" (Derrida 2006: xx). Because of this power, the figure of the spectre can play with its own credibility and superior knowledge and manipulate others. It is in this function that the spectral figures are examined in their relation to power and authority by Grzegorz Koneczniak in his article on "Supernatural beings and their appropriation of knowledge and power in The Seafarer by Conor McPherson and Woman and Scarecrow by Marina Carr." Koneczniak situates his discussion within the context of the spectral turn in contemporary Irish drama, referring to the tradition described by Morash and Richards as "the theatre of ghosts of a ghost, its spectral effect doubled" (2013: 178) and pointing to some possible directions for future investigation. His analysis focuses on the roles of the supernatural figures in two plays by contemporary Irish playwrights. In The Seafarer, the protagonist Sharky is manipulated by devil-like Mr. Lockhart into a game of cards whose stakes are life-and-death; in Woman and Scarecrow, the former is on her deathbed and the latter, invisible to

${ }^{1}$ For the discussion of the meaning of the past and spectrality see Jameson (2008), Derrida (2006), Abraham (1994). 
all but the dying character, accompanies her last moments while disclosing secrets from Woman's life. Imbued with authority derived from intimate knowledge that seems to be attributed to their otherworldly provenance, Mr. Lockhart and Scarecrow control the human characters much like an author may direct their fictional characters: it is through revision, confrontation of perspectives and revelation of secrets that their control can be undermined, even if only partly.

The last area of authorship explored in this volume is the relation of the author to life writing. With its boundary crossing, indeterminacy and genre fusions, life writing reflects, as Zachary Leader argues, "a wider distrust of fixed forms, simple or single truths or meanings, narrative transparency, objectivity, 'literature' as opposed to writing" (2015: 2). Being "best viewed," as Marlene Kadar notes, as "a continuum [...] spread[ing] from the so-called least fictive narration to the most fictive" (1992: 10), life writing can be approached as "a critical practice" which employs the reader's self-consciousness developed in the process of reading to "humanize and make less abstract (which is not to say less mysterious) the self-in-the-writing" (1992: 12). This practice of inclusion and reading across various forms of writing has been central particularly to the reconstruction of women writers' position in the field of auto/biographical writing traditionally dominated by male authors (Cook and Culley 2012: 1-2).

The issues of life writing by women and the self-in-the-writing are discussed in the last article in this volume, “The (Self)portrait of a Writer: A Hermeneutic Reading of Virginia Woolf's (Auto)biographical Writings" by Małgorzata Hołda, who investigates the process of becoming an author by analysing the complex relations between Woolf's fictional and autobiographical texts and the writer's life and work. Hołda's explorations are framed by Paul Ricoeur's hermeneutic approach to identity and Michel Foucault's notion of discourse, and describe the questioning of the boundaries between life and text, and fiction and non-fiction in Woolf's oeuvre. The first part of the essay brings together Woolf's fictional and non-fictional works to present them as mutually illuminating and forming "a unique self-narrative." In the second part, Hołda refers to Ricoeur's concept of narrative identity to examine Woolf's portrayal of the human self as contingent and formed by a variety of experiences and influences. The final part of the article turns to Foucault's ideas on identity and discourse to describe the self's constant disappearance and to analyse Woolf's practice of blurring the boundaries between self and Other, and writer and reader. In effect, Hołda's reading of Woolf's work presents the writer as an interpreter of life and of her own prose, acutely aware of the indispensability of interpretation and the intangibility of the human self.

The articles gathered in this volume aim at describing numerous ways of reading restricted by various kinds of constraint, whether personal or public, past or present, material or spectral. They are all informed by the awareness that any text is always multiple and that all texts are effects and vehicles of power. More importantly, their existence is made possible by Barthes's textual homicide and the realization that any book, including the plays, autobiographical texts, and artworks the authors discuss, is "caught up in a system of references to other books, other texts, other sentences: it is a node within a network" (Foucault 1972: 23).

\section{Works Cited}

Abraham, Nicolas. 1994. "Notes on the Phantom: A Complement to Freud's Metapsychology" (1975). In: Nicolas Abraham and Maria Torok. The Shell and the Kernel: Renewals of Psychoanalysis, ed. and trans. Nicholas T. Rand. Chicago, London: University of Chicago Press, 171-76.

Alexander, Jeffrey C. 2004. "Towards a Theory of Cultural Trauma." In: Cultural Trauma and Collective Identity. Berkeley: University of California Press, 1-30. 
Barthes, Roland. 2000. “The Death of the Author.” In: Nigel Wood and David Lodge (eds). Modern Criticism and Theory: A Reader. Harlow, England: Pearson, 146-50.

Burke, Seán. 1999. The Death and Return of the Author: Criticism and Subjectivity in Barthes, Foucault and Derrida. Edinburgh: Edinburgh University Press.

Burke, Seán. 2006. "Introduction: Reconstructing the Author." In: Seán Burke (ed.) Authorship: From Plato to the Postmodern. A Reader. Edinburgh: Edinburgh University Press, xv-xxx.

Caruth, Cathy. 1995. "Introduction." In: Cathy Caruth (ed.). Trauma: Explorations in Memory. Baltimore: Johns Hopkins University Press, 151-57.

Caruth, Cathy. 1996. Unclaimed Experience: Trauma, Narrative, and History. Baltimore: Johns Hopkins University Press.

Cook, Daniel, and Amy Culley. 2012. "Introduction: Gender, Genre and Authorship." In: Daniel Cook and Amy Culley (eds). Women's Life Writing, 1700-1850: Gender, Genre and Authorship. Basingstoke: Palgrave Macmillan, 1-8.

Derrida, Jacques. 2006. Specters of Marx: The State of the Debt, the Work of Mourning and the New International. Trans. Peggy Kamuf. NY, London: Routledge.

Felman, Shoshana and Dori Laub. 1992. Testimony: Crises of Witnessing in Literature, Psychoanalysis, and History. London: Routledge.

Foucault, Michel. 1972. The Archeology of Knowledge and The Discourse on Language. Trans. A. M. Sheridan Smith. New York: Pantheon Books.

Foucault, Michel. 2000. "What is an Author?" In: Nigel Wood and David Lodge (eds). Modern Criticism and Theory: A Reader. Harlow, England: Pearson, 174-87.

Gallop, Jane. 2011. The Deaths of the Author: Reading and Writing in Time. Durham: Duke University Press.

Hirsch, Marianne. 2008. "The Generation of Postmemory.” Poetics Today 29.1, 103-28.

Jameson, Fredric. 1993. "Postmodernism and Consumer Society" (1988). In: Ann Gray and Jim McGuigan (eds). Studying Culture: An Introductory Reader. London: Edward Arnold, 192-205.

Jameson, Fredric. 2008. "Marx's Purloined Letter." In: Michael Sprinker (ed.). Ghostly Demarcations: A Symposium on Jacques Derrida's Specters of Marx. London: Verso, 26-67.

Kadar, Marlene. 1992. "Coming to Terms: Life Writing from Genre to Critical Practice." In: Marlene Kadar (ed.). Essays on Life Writing: From Genre to Critical Practice. Toronto: University of Toronto Press, 3-16.

Kaplan, E. Ann. 2005. Trauma Culture: The Politics of Terror and Loss in Media and Literature. New Brunswick: Rutgers University Press.

Leader, Zachary. 2015. "Introduction." In: Zachary Leader (ed.). On Life-Writing. Oxford: Oxford University Press, 1-6.

Malkin, Jeanette R. 1999. Memory-theater and Postmodern Drama. Ann Arbor: Michigan University Press.

Morash, Chris, and Shaun Richards. 2013. Mapping Irish Theatre: Theories of Space and Place. Cambridge: Cambridge University Press.

Stuart Fisher, Amanda. 2020. Performing the Testimonial: Rethinking Verbatim Dramaturgies. Manchester: Manchester University Press.

Summerskill, Clare. 2021. Creating Verbatim Theatre from Oral Histories. New York: Routledge. 